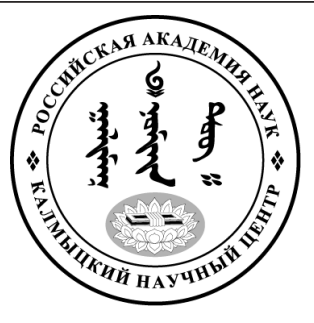

Published in the Russian Federation

Oriental Studies (Previous Name: Bulletin of the Kalmyk Institute

for Humanities of the Russian Academy of Sciences)

Has been issued as a journal since 2008

ISSN: 2619-0990; E-ISSN: 2619-1008

Is. 5, pp. 945-956, 2019

DOI: $10.22162 / 2619-0990-2019-45-5-945-956$

Journal homepage: https://kigiran.elpub.ru

УДК $81373.21+811$

\title{
Лингвистическая рецепция топонимов центральноазиатской геолокации (тюрко-монгольский ареал)
}

\author{
Нурбек Рахматуллаевич Акматов ${ }^{1}$, Сайфулла Нурмухамедович Абдуллаев ${ }^{2}$, \\ Владимир Наранович Мушаев \\ ${ }^{1}$ Иссык-Кульский государственный университет им. К. Тыныстанова (д. 103, ул. Абдрахманова, \\ 722200 Каракол, Киргизская Республика) \\ кандидат филологических наук, доцент \\ ORCID: 0000-0003-4159-8355. E-mail: nurbek_akmatov_76@mail.ru \\ ${ }^{2}$ Иссык-Кульский государственный университет им. К. Тыныстанова (д. 103, ул. Абдрахманова, \\ 722200 Каракол, Киргизская Республика) \\ доктор филологических наук, профессор \\ ORCID: 0000-0003-2873-6397. E-mail: igu@issyk-kul.kg
}

${ }^{3}$ Калмыцкий государственный университет (д. 11, ул. Пушкина, 358000 Элиста, Российская Федерация)

доктор филологических наук, профессор

ORCID: 0000-0001-8321-7667. E-mail: mushaev_vn@mail.ru

Аннотация. Введение. Внимание исследователей постоянно привлекало присутствие монголизмов в тюркских языках, а в монгольских языках - тюркской лексики. Обычно общую тюрко-монгольскую лексику делят на две группы. Как полагают ученые, одна из них восходит к глубокой древности, к языку, письменно не засвидетельствованному; другая появилась в результате взаимных политических, экономических и культурных связей между различными монгольскими и тюркскими народами, главным образом в средних веках. Представляется интересным проникновение монгольских (калмыцких) топонимов в киргизский язык. Известно, что монгольские топонимы проникали на территорию Киргизии двумя путями: вместе с монголами в XIII в.; киргизы, пришедшие на Тянь-Шань из Южной Сибири и Центральной Азии, могли принести с собой ряд монгольских топонимов и нарицательных географических терминов в Среднюю Азию. Многие считают, что в топонимах сохранились следы былой киргизско-монгольской языковой взаимосвязи (очевидно, периода Джунгарского ханства). Цели и задачи. Тюрко-монгольское этническое мировосприятие центральноазиатской геолокации по причине историко-географической общности судеб монголов и тюрков сформировало близкий и стойкий взгляд на систему номинации, которая менялась в зависимости от миграционных процессов. Наиболее консервативным пластом этой лексики являются топонимы. Maтериалы u методы. В данной статье рассматриваются топонимы тюрко-монгольской (калмыцкой, киргизской, монгольской) лексической общности, их ареальное распространение, семантика и вопросы этимологии. Исследуются киргизские географические имена, которые восходят к апеллятивам генетически родственных языков, и монгольские топонимы, появившиеся в результа- 
те взаимодействия народов. В качестве иллюстративного материала приводятся фрагменты из легенд и преданий. Изучаемый материал может быть использован в ареальной лингвистике, сравнительно-исторических и типологических исследованиях, в общем и частном языкознании. Применяется сравнительный метод параллельного семантического анализа топонимов родственных и близкородственных языков. Результаты. Этническое мировосприятие тюрков и монголов опирается на общий историко-хозяйственный опыт и визуальную память, которые являются свидетельством тесных тюрко-монгольских связей. В работе исследованы топонимы калмыцкого и киргизского языков как наиболее устойчивый к изменениям пласт лексики. Рассмотренный материал позволяет утверждать, что монголизмы чаще всего встречаются в собственно-географических наименованиях в северных регионах Киргизии, по мере продвижения на юго-запад они встречаются реже. В изучаемой региональной топонимике просматривается историко-хронологическая периодизация топонимической системы конкретного языка, которая тесно связана с ландшафтом, терминами и онимами данной местности. Для всего евразийского ономастического пространства характерно обилие сходных тюрко-монгольских географических названий. Исследуемая нами геолокация тюркских и монгольских районов Киргизии обнаруживает наличие устойчивых параллелей в топонимических наименованиях и используемых при этом апеллятивов.

Ключевые слова: топоним, гидронимы, ареал, этимология, семантика, ойконим, оним Благодарность. Исследование выполнено при поддержке внутривузовского гранта КалмГУ в рамках проекта «Монгольское и тюркское языкознание: традиции и инновации»

Для цитирования: Акматов Н. Р., Абдуллаев С. Н., Мушаев В. Н. Лингвистическая рецепция топонимов центральноазиатской геолокации (тюрко-монгольский ареал). Oriental Studies. 2019;(5): 945-956. DOI: 10.22162/2619-0990-2019-45-5-945-956.

UDC $81373.21+811$

\title{
Central Asian Geolocation: Linguistic Reception of Toponyms (Turko-Mongolic Area)
}

\author{
Nurbek R. Akmatov ${ }^{1}$, Saifullah N. Abdullaev², Vladimir N. Mushaev ${ }^{3}$ \\ ${ }^{1}$ Tynystanov Issyk-Kul State University (103, Abdrakhmanov St., Karakol 722200, Kyrgyz Republic) \\ Cand. Sc. (Philology), Associate Professor \\ ORCID: 0000-0003-4159-8355. E-mail: nurbek_akmatov_76@mail.ru \\ ${ }^{2}$ Tynystanov Issyk-Kul State University (103, Abdrakhmanov St., Karakol 722200, Kyrgyz Republic) \\ Dr. Sc. (Philology), Professor \\ ORCID: 0000-0003-2873-6397.E-mail: igu@issyk-kul.kg \\ ${ }^{3}$ Gorodovikov Kalmyk State University (11, Pushkin St., Elista 358000, Russian Federation) \\ Dr. Sc. (Philology), Professor \\ ORCID: 0000-0001-8321-7667.E-mail: mushaev_vn@mail.ru
}

\begin{abstract}
Introduction. Mongolisms in Turkic languages and Turcisms in Mongolic ones have constantly been objects of research interest. The whole of common Turko-Mongolic vocabulary is usually divided into two groups: the first one is believed to have stemmed from a most ancient nongraphic language, and the second one supposedly resulted from mutual political, economic and cultural contacts between diverse Mongolic and Turkic populations primarily in the Middle Ages. Mongolic (Kalmyk) borrowings in the Kyrgyz language are interesting enough. As is known, Mongolian toponyms had penetrated into Kyrgyzstan either during the 13-century Mongolian expansion, or during the Kyrgyz migrations from South Siberia and Central Asia to the Tian Shan accompanied by inflows of Mongolian toponyms and appellative place names. It is also believed by many that the toponyms retain traces of Kyrgyz-Mongolian language contacts (evidently those of the Dzungar period). Goals and Objectives. As a result of historical and geographical affinities between Turkic and Mongolic populations, the Turko-Mongolian ethnic perception of Central Asian geolocation had
\end{abstract}


established close and largely identical approaches to the system of nomination that would change pursuant to migration processes. And those are toponyms that constitute a most conservative (rigid) lexical cluster. Materials and Methods. The paper examines common Turko-Mongolian (Kalmyk, Kyrgyz, Mongolian) toponyms, their areal distribution, semantics and etymology; analyzes Kyrgyz place names that stem from appellatives of genetically related languages and Mongolian toponyms that emerged during language contacts. The study involves lexical analysis of some legends and tales. The materials investigated can be further used in areal linguistics, comparative historical and typological studies, general and special linguistics. The work employs the method of parallel semantic analysis of toponyms from related and closely related languages. Results. Ethnic worldviews of TurkoMongols are based on common historical and economic experiences, visual memories that indicate close ties and interactions. The paper focuses on Kalmyk and Kyrgyz toponyms that form most rigid lexical clusters. As is shown, Mongolisms are most frequent in Northern Kyrgyzstan place names but are get rarer towards the southwestern territories. The examined regional toponymy illustrates historical / chronological periods inherent to the language toponymic systems closely associated with landscapes, terms and onyms of certain localities. The whole of the Eurasian onomastic space is characterized by abundance of similar Turko-Mongolian place names. The investigated geolocation of Turkic and Mongolic regions of Kyrgyzstan manifest stable parallels it terms of toponyms and respective appellatives employed.

Keywords: toponyms, hydronyms, area, etymology, semantics, place name, onym

Acknowledgements: The reported study was granted by Gorodovikov Kalmyk State University, project name 'Mongolian and Turkic Linguistics: Traditions and Innovations.

For citation: Akmatov N. R., Abdullaev S. N., Mushaev V. N. Central Asian Geolocation: Linguistic Reception of Toponyms (Turko-Mongolic Area). Oriental Studies. 2019;(5): 945-956. DOI: 10.22162/2619-0990-2019-45-5-945-956.

\section{छे}

Ученых-лингвистов издавна интересовал вопрос, касающийся взаимодействия тюркских и монгольских языков. Вопросам тюрко-монгольских языковых общностей посвящены многие работы: [Рамстедт 1957; Владимирцов 2005; Поливанов 1991; Малов 1951; Баскаков 1978; Рассадин 2008; Бертагаев 1971; Санжеев 1947; Убрятова 2011; и др.].

Топонимика - область ономастики, неизменно привлекающая внимание тюркологов и монголоведов. Вопросам топонимики на материале тюркских языков посвящены работы ученых: [Абрахманов 1975; Саттаров 1998; Монраева 2014; Абдуллаев 2007; и др.].

В монгольском и калмыцком языкознании топонимическая проблема затрагивается [Рассадин 2008; Хонинов 2013] и другими авторами.

Монгольские заимствования в киргизской лексике исследуются в работах [Батманов 1966; Юнусалиев 1959; Орузбаева 1995; Сыдыков 1983; Конкобаев 1980; Сулайманова 2009] и других исследователей.

Монголизмы в других тюркских языках, в частности уйгурском, изучались А. Т. Кайдаровым и др. [Строй 1989: 76].
Так, С. Сыдыков общую тюрко-монгольскую лексику делит на две группы: «Одна из них, первичная, восходит к глубокой древности, к языку, не засвидетельствованному временем; другая - вторичная, появилась в результате взаимных, политических, экономических и культурных связей между различными монгольскими и тюркскими народами главным образом в средних веках» [Сыдыков 1983: 24].

Профессор Г. Д. Санжеев отмечает, что киргизский язык всегда соприкасался с монгольским, и между этими языками обнаруживается немало лексических параллелей, что говорит о многочисленных взаимных заимствованиях [Санжеев 1947: 69].

Топонимы традиционно причисляются к числу важнейших индикаторов культуры. «Созданные на разных языках, в разное время, они отражают всю многовековую историю народа: природные условия его существования, материальную и духовную жизнь в их непрерывном развитии» [Ондар 2007: 3].

Обращаясь к топонимам тюрко-монгольского ареала, мы преследуем цель осмыслить межъязыковые параллели в сфере 
центральноазиатской геолокации, ограниченной территориями современных Тувы и Киргизии, а также географическим пространством между ними, известным под названиями Восточный Туркестан или Синьцзян-Уйгурский автономный район (СУАР) КНР, на территории которых разворачивались основные процессы «обкатки» топонимических единиц. Эти процессы подразумевают становление типичных моделей образования топонимов.

Авторы, специально проводившие исследования на языковом материале СУАР КНР, выделяют следующие основные тюркские топонимические модели:

1) прилагательное + существительное: Yengi Daban 'Новый горный перевал', Kizil Daban 'Красный перевал' и др.;

2) существительное + существительное: Sogat Bulak 'Родник ивы', Qig Su 'Канава ила' и др.;

3) числительное + существительное: Tokkuz Dawan 'Девять горных перевалов’ и др.;

4) сочетание существительного, являющегося определением, с существительным, выступающим в роли определяемого и оформленным аффиксом принадлежности третьего лица (конструкция «турецкого изафета»): Aktagningbexi Shan 'Белая горная вершина' [Монраева 2014: 94].

Тюркский пласт топонимов в СУАР представлен наиболее широко соответственно уйгурскими и казахскими топонимами [Монраева 2014: 95]. Вместе с тем, по мнению того же автора, на территории исследуемых районов пласт монгольских топонимов представлен не менее широко.

Можно выделить следующие особенности образования монгольских топонимов на территории СУАР:

1) образуются из односложных слов: Kerxi 'крутой склон', Modir 'древесина, деревянный', Jandilik 'прохладный';

2) образуются из сложных слов: Karazagte 'черная древесина саксаула', Ulanburan 'красная ива';

3) образуются из словосочетаний, в которых обычно определение (зависимое слово) стоит в препозиции, а главное (географический термин) - в постпозиции, например: Bayan nuиr 'Богатое озеро', Dabsinkora 'овчарня из солончака', Nogansay 'зеленое пастбище', Qagan
Gol Kuygani 'место слияния Белой реки', Herginobo 'горный проход с узким ущельем' [Монраева 2014: 94].

Киргизстан - горная страна, богатая белоснежными вершинами, замысловатыми хребтами, перевалами, поэтому в его топонимике преобладает онимическая терминология, тесно связанная с ландшафтом данной местности. Именно поэтому многообразием горных ландшафтных онимов киргизская топонимика заметно отличается от монгольских (калмыцких) онимов. Однако равнинные онимы во многом схожи. Статья содержит лингвистические, географические и исторические сведения, т. е. данные смежных дисциплин.

Что касается монгольских топонимов, то они, по предположению Э. М. Мурзаева, проникали на территорию Киргизии двумя путями: 1) вместе с монголами в XIII в.; 2) киргизы, пришедшие на Тянь-Шань из Южной Сибири и Центральной Азии, могли принести с собой ряд монгольских топонимов и нарицательных географических терминов в Среднюю Азию [Мурзаев 1970: 62-65].

Интересной представляется точка зрения И. А. Батманова, который отмечает три периода проникновения монголизмов в киргизский язык: 1) в енисейский период; 2) в XII-XIV вв.; 3) во время господства джунгарцев [Батманов 1966: 20].

Как явствует из высказывания Б. О. Орузбаевой, «в топонимах сохранились следы былой кыргызско-монгольской языковой взаимосвязи (в основном периода Джунгарского ханства), что косвенно подтверждается и тем, что монголизмы чаще встречаются в собственных географических наименованиях в Северной Киргизии, но по мере продвижения на юго-запад они встречаются все реже» [Орузбаева 1995: 116]. Действительно, на примере киргизской топонимии мы убедились в том, что монголизмы количественно преобладают на севере Кыргызстана.

Распространение и исчезновение монгольского языка в Средней Азии, по мнению Ц. Д. Номинханова, охватывает три периода [Номинханов 1966: 14].

Достаточно вероятной представляется точка зрения тюрколога К. Конкобаева об общности тюрко-монгольских языков [Конкобаев 1980: 72]. 
Народные географические термины в топонимии Кыргызстана послужили основой для утверждения Л. С. Сулаймановой о генетическом родстве киргизско-монгольских языков [Сулайманова 2009: 48].

Целевая установка статьи заключается в верификации гипотезы о консервативности топонимического мировосприятия этносов тюрко-монгольской общности центральноазиатской геолокации. Мы предполагаем, что историко-географическая общность судеб тюрков и монголов детерминировала необходимость устойчивой системы номинации, которая является следствием миграционных процессов и локативной характеристики бытия тюрков и монголов.

Рассмотрим ряд гидронимов и топонимов в отдельности. Подобный подход достаточно рельефно покажет взаимосвязь этих двух семантически близких пластов онимов. При этом монгольские (калмыцкие) онимы рассматриваются нами на фоне тюркских географических названий. Своеобразный топонимический ландшафт Киргизии вызывает особый интерес. Каждый оним имеет географическую привязку, семантику, а некоторые и происхождение. Необходимо подчеркнуть, что одно географическое название может выступать в качестве оронима, гидронима и ойконима. В данном случае речь идет об омонимах в топонимии, о чем свидетельствуют нижеприведенные названия. При сопоставлении киргизских, уйгурских и других тюркских топонимов отметим различающуюся специфику в их написании, что само по себе составляет особую проблему [Абдуллаев 2007: 174]. В тувинских топонимах принято последовательное написание через дефис, в уйгурских и казахских - слитное написание, а в киргизских - смешанное и допускающее оба варианта. Итак, обратимся к конкретному материалу.

Алтын-Булак - название родников: 1) в долине Каркыра; 2) в горах близ с. Энчилеш (оба родника находятся в Иссык-Кульской области); 3) родник в горах Укек, на территории с. Исакеева Нарынской области [Словарь 1988].

Первый компонент топонима алтылн (кирг. алтын, калм. алтн, монг. алтан) означает «золото». Махмуд Кашгари объясняет значение слова алтын как «алды - ниж- ний», «асты - находящийся внизу» [Кашгари 2012: 225].

Э. М. Мурзаев пишет, что: «алd, aлm нижняя сторона, низ, основание; тюрк. в топонимии - подошва горы [Мурзаев 1984: 47-48].

Второй компонент булак означает «родник»: кирг. булак, калм. булг [РКС 1940: 256], монг. булаг [КМРС 1947: 35].

Арал - название сёл в Тюпском и Жумгалском районах, арал означает 'остров': кирг. арал, монг. арал [КМРС 1947: 20], калм. арл [РКС 1940: 180]. Ойконим арал происходит от островка, возникшего на реке Тюп.

Арашан - в киргизском языке название речки, местности, ущелья и родника в Ак-Суйском p-не. В Чуйской области имеется село с таким же названием. Калм. apшан: 1) целебный (минеральный) источник [КРС 1977: 52]; кирг. арашан, монг. аршаaн: 1) святая вода; 2) минеральная вода; 3) целебный источник, курорт [КМРС 1947: 22]. Некоторые ученые предполагают, что слово арашан заимствовано из санскритского языка. Имеется орфографический вариант: нарзан. [Агеева 2012; Мурзаев 1984; Аристов 2001]

Белчир. В киргизском языке апеллятив белчир имеет следующие значения: 1) болезнь скота; 2) сапоги, сшитые из кожи лошади [КТТС 1969: 97]. Калм. белчр - пастбище [РКС 1940: 191], перекрёсток [РКС 1940: 195], подножие [РКС 1940: 207], устье [РКС 1940: 308], например: голин белчр устье реки [РКС 1940: 308]. Кирг. билчир: 1) место слияния (рек); 2) ж-д узел [КТТС 1969: 31]. Монг. бэлчээр - пастбище, кирг. жайыл - пастбище [КТТС 1969: 31]. Например: суунун белчири, же айрыльш жери 'разлив реки'.

Беш-Мойнок - левый приток р. Сары-Жаз. Көк-Мойнок - монг. хөх мойног. В ущелье Барскоон, не доезжая перевала Барскоон, находится перевал Сары-Мойнок. В топониме Беш-Мойнок определение беш означает 'пять', здесь имеется пять таких местностей. В кирг. мойнок имеет 4 значения: Мойнок 1) малдын жана кийиктин моюн териси; 2) төөнүн мойнунун ийри жери; 3) моюну ак ала болгон ит; 4) ийри белес, өркөчтөнгөн '1) шкура шеи скота и горного козла; 2) изгиб шеи верблюда; 3) собака черно-белого окраса; 
4) волнистое подножие' ${ }^{1}$ [Каратаев 2003: 231].

В словаре К. К. Юдахина «мойнок крутой горный перевал» [Юдахин 1965: 430]. Монг. мойног - угловатый, кривой. Монг. сарну - 'кривой, пологий' [Исаев 1977: 18]. И это значение служит основанием расшифровки топонима Capbl-Мойнок.

Бугучу. В калм. и монг. бууи 1) стоянка, стойбище; 2) усадьба [Батманов 1966: 92]. Монгольский $\boldsymbol{\varphi}$ в кирг. яз. переходит в $\boldsymbol{\varphi}$.

Буркан - ледник, озеро, долина во Внутреннем Тянь-Шане, в долине Сырт находится и река с таким названием. Название близко к монг. бурхан [Исаев 1977: 37], калм. бурхн [КРС 1977: 23], означающему ‘бог’. В «Диалектологическом словаре» Ж. Муканбаева: «Буркан - эвфемизм» [Муканбаев 1972: 59]. Слово бурхан перешло в монгольский язык из тюркского. По информации географа-топонимиста Т. Эшенкулова, «Буркан - калмыцкое слово, на карте записано как Бурхан. Бууракан и Буркан - одно и то же» [Эшенкулов 1985: 185-186].

Буура. Компонент буура сохранен в топонимах Ак-Буура и Кара-Буура. В кирг. яз. значение буура: тукумдатуучу төө - буура (сущ.) 'племенной верблюд’ [Каратаев 2003: 125]. В калм. бура 'прут, розга' [КРС 1977: 238].

К. Конкобаев и историк О. Каратаев считают, что это название рода (племени). У географа-топонимиста С. Умурзакова по топониму Ак-Буура имеется специальное исследование. Возможно, Ак-Буура 'белая река' образовано от ледника, а Кара-Буура 'черная река' или 'большая река' - от грунтовых, подземных вод [Умурзаков 1985: 37].

Балта. Компонент балта встречается в составе топонима Кара-Балта - гора, река и город в Северном Киргизстане. В кирг. яз. балта - орудие труда из железа [Каратаев 2003: 84]. В калм. балт - боевой топор, секира [КРС 1977: 80]; в монг. балт - молот, кувалда [Исаев 1977: 27]. Ученые считают, что топоним Кара-Балта происходит от названия рода (племени) [Орузбаева 1995; Каратаев 2003].

Согласно исследованиям О. Каратаева, лексема балта в кара-балта (досл. 'черный топор'), возможно, относится к этническим тюркским названиям балта (балталь) -

1 Здесь и далее перевод с киргизского языка на русский наш. - прим. авт. название рода у казахов, узбеков, азербайджанцев. Этнонимы балта, кара-балmа, балталь встречаются в Узбекистане и Азербайджане. В данном случае прилагательное кара не обозначает черный цвет, а употребляется в своем древнем значении - «большой, много», т. е. великий, многочисленный.

Гол (көл). В калм. гол - река; Ижсл мөрн һол - река Волга. Компонент мөрн означает 'большой' [КРС 1977: 165]. В монг. гол: 1.1) река, 2) ось, 3) вал; 2.1) главный, центральный [Исаев 1977: 32]. В Киргизстане это слово встречается в сложных топонимах: Жумгал, Каракол, Улакол (Улахол).

Даба /даба(н) - в тувинском языке монгольское заимствование с семантикой «горный перевал» [Ондар 2007: 32]. В уйгурском языке апеллятив-монголизм даван встречается в популярной народной песне о красавице из Даванчина, геолокации, названной по аналогии с одноименным перевалом на трассе из Урумчи в Турфан. В топонимике Тувы апеллятив встречается преимущественно в сложных наименованиях: Модун-Даба, Көк-Даба.

Долон. Перевал Долон относится ко Внутреннему Тянь-Шаню. В эпосе «Манас» Долон описывается как один из перевалов Ала-Тоо.

Топонимист Д. Исаев отмечает, что сведения о Долон у народа не помогают раскрыть значение этого топонима, но предполагая, что в старину это могло называться долоон, дулаан, приходит к выводу, что это слово претерпело фонетическое изменение, и слово долоон в монг. означает «семь». Автор далее пишет, что «семь» употреблено не только в значении цифры, но и в значении «много». Во-вторых, монгольское долан, даланг связано со словами вершина, ребро, спина и привязка, изгиб. Д. Исаев пишет: «Долон употреблён в значении „кривой, сложный“» [Исаев 1977: 34].

Кроме этого, существует предположение, что перевал назван в честь Долон-бия, выходца из киргизского народа, могила которого находится на перевале.

Жагалмай - название ледника и реки. Ледник Жагалмай - пик сложной долины на пересечении гор Чакыр-Корум и Борколдой. Длина ледника - 9,6 км. Находится в правом притоке реки Чон-Нарын. С ледника начинается речка Жагалмай. 
Жагалмай - так называют киргизы и небольшую хищную птицу из семейства соколиных - чеглок, она не относится к ручной группе. В калмыцком и монгольском языках встречается в форме заһлма/ загалмай [КРС 1977: 96]. Звукобуква ж⿻ из кирг. яз. замещается з в калм. и монг. яз. Топоним Жагалмай назван по сходству: пик напоминает форму птицы чеглок.

Жумгал - река. В калм. и монг. зҮYн левый [КРС 1977: 122]; гол - река, гидроним Жумгал образован от значения «левая, или восточная, река». Действительно, река Жумгал является левым притоком Кокомерена.

Казан-Куйган - название села и реки в Нарынском р-не. Ойконим появился от названия реки. Определяющее слово казан означает 'котел': кирг. казан, калм. хәәсн. Слово куйган - кольчуга: кырг. куйган, калм. хуйг [КРС 1977: 112]. Слово казан в тюрк. и монг яз. означает также «яма, низина между горами» [Кашгари 2012: 81]. Гидроним появился на основе метафорического сходства: вода вытекает из низины в горной местности, очертаниями напоминающей котел.

Географические термины Куйган, учар, секирик являются компонентами топонимов Казан-Куйган, Өрдөк-Учар, Теке-Секирик, встречаются на Алтае в наименованиях местности и рек, а в Киргизстане в основном эти названия связаны со словом водопад.

Кан-Тенгир - название горы, пика. Горная вершина в восточной оконечности территории Киргизии, вторая по высоте на Тянь-Шане. В кирг яз. Кан-Теңцир, в монг. яз. Хан Теңэгэри. В кирг. теңчир - 'небо, бог', а в калм.: 1. хан, царь, монарх; тенгр — небо, небеса [КРС 1977: 493], монг. тэнгэр - небо [Исаев 1977: 24].

В народе имеется легенда о Кан-Тенгире. Это название объясняется тем, что под красноватыми закатными лучами солнца верхняя часть вершины становится почти красной, а тени от проносящихся над ней облаков создают подобие стекающих с нее красных струй.

Местные называют эту гору Кан-Тоо (в переводе «Кровавая Гора»), возможно, изза красного цвета, который гора Кан-Тенгир принимает во время заката, или же из-за того количества альпинистов, которые погибли при восхождении на эту гору.
Как представляется, топоним происходит от тюрко-монгольского кан/хаан 'правитель, монарх' и тенгри 'небо, бог', означает «повелитель неба». Название Кан-Тоо дано местными иссык-кульскими киргизами за колоссальную высоту по сравнению с остальными горными вершинами.

Кара-Кужур (в монг. хархуджир мало солончаковая местность), Дөрбөлжүн (дөрвөлжсин - четырехугольник). Сары-Тологой (иар толгой 'пик горы'), Оргочор (Орнгоньцор - отдельная гора), Кызыл-Омпол (красная гора), Түргөн (монг. түргэн: 1) скорый, быстрый, спешный [Исаев 1977: 20]). Көкөкулусун (хөх хулсан) зеленый камыш, калм. көк [КРС 1977: 266], в калм. яз. көк хулсн - зеленый камыш [KPC 1977: 106].

Каранар - навание местности, холм в Ак-Суйском р-не, прежнее название с. Каракол (совхоз Каракол) Ак-Суйского р-на. В калм. и монг. яз. наран, нар - солнечный [Батманов 1966: 100]. По мнению Д. Исаева, название местности связано с этим значением. По нашему предположению, топоним Каранар мог возникнуть по переносу значения 'верблюд’. На этой территории встречаются оронимы Чон-Каранар, Орто-Каранар и Кичи-Каранар. Речь идет о величине объектов: чон, орто, кичик.

Кегети. Киргизское слово гэгэти означает «блестящий». В калм. гегәтә - «освещенный». В топониме Кегети аффикс -mbl/-mи является измененным вариантом древнего аффикса множественности -льг. По нашему мнению, значение слова кегети связано со значением слова кеген.

Кемер. 1) сырт жагына күмүш чаптырылган, кооздолгон жазы кайыш кур, илгич; 2) суу жеп кеткен жээк, жарча '1. покрытый серебром широкий кожаный ремень; 2) берег, омываемый водой' [Каратаев 2003: 205]. Кичи-Кемер, Чон-Кемер - названия местности и ущелья в Ак-Суйском р-не. Keмер созвучно с калм. хамр и монг. хамар: 1) нос, рыло; 2) угол; 3) костяной наконечник; 4) коса [Исаев 1977: 26].

Керей-Шорон - село в Ошской обл. Имеется и село под названием Шорон. Имеется предположение, что топоним происходит от названия рода (племени). К этому мнению можно присоединиться. По нашему исследованию, керейт - название племени семейства рода төөлөс, а второй компонент 
в монг. щорон(г) - одиночная высокая гора, отдельная гора [Исаев 1977: 20]. Одна часть племени керейт проживает в с. Аң-Өстөн (Ак-Устен) Жеты-Огузского р-на, вызывает интерес их проживание на восточной части холма Оргочор. Этноним кереит представляет собой древнее тотемное имя с монгольским корнем хэрээ, передаваемое по-русски как кере, кэрэ, хэрэ и означающее 'ворон' [Хойт 2008].

Кептеш - название местности в Ат-Башинском р-не, село Кара-Кулжи и Ноокенских районов; озеро Эңилчек в сыртах Сары-Жаз называлось Кептеш. В калм. яз. кевтр: 1. постель; 2. лежка; 3. логово; [КРС 1977: 288], монг. хэвтэш - лёжка скота. Этот топоним встречается и в эпосе «Манас». В кирг.: «эки тарабы кууш, тар кокту, колот» [Каратаев 2003: 208] - «с двух сторон узкая, маленькая ложбина». Kenтеш «узкий, маленький лог, ложбина».

Коңулгу-Суу - название долины, реки и ледника в горах Сары-Жаз. В монг. яз. означает 'пещера', калм. гу - долина [КРС 1977: 71], второй компонент гу означает 'русло' [КРС 1977: 256]; в монг. гуy: 1) ров, канава; 2) рама [Исаев 1977: 35]. Значит, можно понимать как «вода из пещеры».

Көдөө - название местности в сыртах ${ }^{2}$. Калм. көдə - степь, пустынная местность; поле [КРС 1977: 311], кирг. көдөө - трава, монг. хөдөө '1) провинция, 2) степь' [Каратаев 2003: 230].

Көк-Кытан - название местности в Тонском рай-не. В калм. көк хутн - цапля [КРС 1977: 316], КТТС: «кытан: ак кытан, көк кытан - длинноногие, длинноклювые, длинношеие болотные птицы» [Каратаев 2003: 205].

Көк-Ойрок. Компонент көк 'зеленый' у данного топонима в калм. көк и монг яз. $x \theta x$ 1.1) грудь, сосок; 2) вымя. 2.1) зеленый (о растительности) 2.3) лазурный [Бертагаев 1971: 98], а компонент ойрог, ойрохь - ближайший, ближний [Исаев 1977: 154].

Көк-Ойрок может быть близок топониму Көк-Айрык. В Кеминской долине имеются перевал, дорога и пастбище с таким названием. В Иссык-Кульской обл. также имеется название пастбищ, а в России, в Ал-

\footnotetext{
${ }^{2}$ Сырт - тип нагорья на Тянь-Шане и Восточном Памире, использующегося как высокогорные пастбища.
}

тайском крае, в знаменитое Телецкое озеро впадает речка Ойрок, известная также как «Третья речка» (имеет она и другие названия: Алтын Кӧл (южноалт.) и Алтылн нуур (монг.), оба топонима переводятся как 'Золотое озеро').

Көңдөй (Кундуй). В калм. көндә - «пустой», «полый» [КРС 1977: 316]. Этот топоним как название местности, речки, встречается в различных формах в Иссык-Кульской и Нарынской областях.

В словаре К. К. Юдахина: «Көндөй пустой, полый». По версии Э. М. Мурзаева, это слово через якут. яз. было принято монг. языком: «Топоним Көңздөй имеет два значения: 1) пространство, низина; 2) ущелье, канал. Хундуй, хунды - широкая падь, широкая долина, просторная котловина между горами» [Мурзаев 1984: 423]; пустой (бур.). Ср. монг. хөдий — «ущелье», «долина», «дупло», «пустой», в диал. «пещера», эвенк. $\kappa ө н[г] \partial \theta-$ «котловина», «пустота», что заимствовано из якут. көндөй - «пустой», «дутый», «полый», «дуплистый». Кундуй с таким названием имеется река в Бурятии, Иркутской и Читинской областях [Конкобаев 1980: 599]. С таким же названием имеется село в Иркутской области РФ.

По-нашему мнению, көңдөй - географический термин, переходящий в топоним. Топонимы Көң̧дөй в Киргизстане появились на основе особенности рельефа местности.

Кудук. Кудук - в горах Тасма Тюпского р-на. Калм. худг, монг. худаг - колодец [КРС 1977: 607]. В кирг. яз.: кудук - зат. Суу чьгаруу жана суу альп туруу Үчүн казылган чунукур 'кудук - сущ. Вырытая яма для употребления воды' [Каратаев 2003: 256].

Кулгуна - название местности в Тонском районе. В калм. хульн и монг. яз. хулгана - мышь [Исаев 1977: 25]. В кирг. кулгуна - область шеи [Каратаев 2003: 259].

Кыргыз көлү, Хырхыс-Нуур. Название озера в Монголии. Калм. нур и монг. нуур - озеро [Исаев 1977: 147]. Достаточно распространенный термин в тюрко-монгольских языках.

Лама, Ылама - название села Жумгальского района. В калмыцко-русском словаре: лама - буддийский монах [КРС 1977: 122].

Существует легенда о девушке-калмычке по имени Лама, которая вышла замуж за 
киргизского джигита и уехала жить в его село (айыл). Увидев, что там люди страдают от нехватки воды, она организовала постройку большого арыка, который обеспечил драгоценный влагой все высокогорное село. В честь этой девушки и был назван этот населенный пункт.

Мукур - название села, речки, озера в Киргизии. Достаточно распространенный термин в топонимике. В калм. мухр означает 'комолый, куцый, тупик’ [КРС 1977: 364]. В словаре К. К. Юдахина имеет 3 значения [Мурзаев 1984: 536]. Э. М. Мурзаев в термине мухар, мухор, мукур, мукыр указывает среди многих значений только: «короткий», «куцый», «короткий тупик» (тюрк., монг.). Термин часто употребляется для названия маловодных степных рек и речек, которые в летнее время часто исчезают, пересыхают. В горах так именуют тупиковые ущелья, не имеющие перевалов в своих верховьях [Конкобаев 1980: 382].

В топонимике Горного Алтая встречается слово мукор/мукр/мухур. Местное население объясняет его значение как расстояние между большим и согнутым указательным пальцами, то есть мера расстояния (вершок). Мукур-Таркатты - букв. короткая (река) Таркатты.

Тюркологи Г. Конкашпаев и Ж. Мукамбаев считают, что слово мукур монгольского происхождения [Конкашпаев 1956; Муканбаев 1976]. Схожее мнение выражают и авторы данной статьи.

Ой. В кирг. яз. является омонимом. В КТТС: Ой, зат. Чунукурураак болуп кеткен жер, ойдун [Каратаев 2003: 458] 'Ой, сущ⿱-е. - Углубление на местности’. В словаре К. К. Юдахина: «Ой - низина, впадина, котловина» [Юдахин 1965: 561]. В монг. ой — лес, бор, роща [Исаев 1977: 25].

Орой-Суу - перевал в сырте Сaры-Джаз (кирг. Сарыжаз). Калм. ора и монг. орой в значении: 1) пик, вершина горы; 2) крыша, макушка [Исаев 1977: 159]. Орой-Суу - «стремительная вода».

Салаа. В калм. сала - балка, проток [КРС 1977: 436]. В кирг. салаa - межгорная ложбина, по которой стекают талые воды.

Салкын-Төр. В калм. салькн и монг. яз. салхи - ветер, ветреный [Исаев 1977: 176]. В Чуйской обл. определение топонима төр означает «пик, вершина горы», а определение салкын в кирг. яз. означает 'прохладный, свежий’. Значит, Салкын-Төр - «прохладный, ветреный пик, вершина».

Сетер (ныне Сарыбай) - пастбище у ущелья Ак-Шыйрак Жети-Огузского района. Название речки, зимовки. Слово сетрә в калм. ' 1 . освященный; 2. жертвенное животное'; в кырг. сетер 'скот для жертвоприношения'.

Тегирменти - название местности и речки Иссык-Кульского района. В калм. теерм - мельница [КРС 1977: 131]. Монг. тээрэм и кырг. тегирмен - мельница.

Темир-Көл - название Иссык-Куля появилось в эпоху Джунгарского ханства. В калм. төмр и монг яз. төмөр - железо; железный [Исаев 1977: 211].

Тепке - село в Ак-Суйском районе. В калм. тебке - деталь калмыцкой домбры [КРС 1977: 487]. В кирг. тепке - лестница. Название села, возможно, произошло на основе внешнего сходства.

Чельпек - название населенного пункта. На калм. цุелвг - круглая лепешка. В данной местности проживали и проживают сарт-калмыки, или каракольские калмыки. В настоящее время они ассимилировались среди киргизов. То же самое произошло с сарт-калмыками в Башкирии.

Шылуун. В калм. шулун «быстрый, скорый спешный; шулун урсхл - быстрое течение» [КРС 1977: 683]. В монг. шулуу(н) прямой, правдивый, честный [Каратаев 2003: 321$]$.

Эмел - название местности в сыртах. Калм. эмәл и монг. эмээл означают 'седло' [Каратаев 2003: 327]. В кирг. эмел - географический термин со значением 'седло'. Названо на основе внешнего сходства. Произошла метафоризация.

Таким образом, суммируя изложенное, можно констатировать, что в представленном материале монгольские (калмыцкие) топонимы достаточно рельефно просматриваются на фоне межтюркских, в частности тувино-киргизских, онимических параллелей. Рассматриваемый материал может быть использован при изучении не только ареальной топонимики, но и в сравнительно-сопоставительных исследованиях с охватом данных разноструктурных языков. В этой связи необходимо отметить, что для тюрко-монголоязычной топонимии характерно обилие сходных географических названий на всем евразийском ономастическом про- 
странстве. Рассматриваемая нами геолокация тюркских и монголоязычных районов Киргизии обнаруживает устоявшиеся параллели в употреблении географических наименований и используемых при этом апеллятивов. На пространстве между двумя регионами обозначенного тюрко-монгольского ареала устоялись процессы «обкатки» моделей используемых топонимических единиц, свидетельствующие о глубоких и устойчивых тенденциях тюрко-монгольского лингвистического взаимодействия.

Геолокативное мышление тюрков и монголов опирается на исторический опыт и сильную визуальную память носителей этих языков, которая свидетельствует о тесных тюрко-монгольских языковых связях. Топонимы остаются консервативной частью лексики, в отличие от, например, антропонимов, попавших под сильное влияние религиозных традиций. Консерватизм данного разряда лексики проявил себя и в новейшее время при замене географических наименований в постперестроечный период, когда возвращались прежние тюрко-монгольские наименования, например, Каракол, Кызыл-Суу и др.

\section{Литература}

Абдрахманов 1975 - Абдрахманов A. A. Топонимика и этимология. Алма-Ата: Наука, 1975. $207 \mathrm{c}$

Абдуллаев 2007 - Абдуллаев С. Н. О вариантности написания топонимов Иссык-Кульского региона // Русский язык в образовательном пространстве Центральноазиатского региона СНГ. Бишкек: Изд-во КРСУ, 2007. C. $173-175$.

Агеева 2012 - Агеева Р. Как появились названия рек и озер. Популярная гидронимика. М.: АСТ-Пресс, 2012. 288 c.

Аристов 2001 - Аристов Н. А. Усуни и кыргызы или кара-кыргызы. Бишкек: Илим, 2001. $578 \mathrm{c}$.

Баскаков 1978 - Баскаков Н. А. Язык прииссыккульских уйгуров. Алма-Ата: Наука, 1978. $49 \mathrm{c}$.

Батманов 1966 - Батманов И. А. Источники формирования тюркских языков Средней Азии и Южной Сибири. Фрунзе: Илим, $1966.360 \mathrm{c}$.

Бертагаев 1971 - Бертагаев T. А. Внутренняя реконструкция и этимология слов в алтайских языках // Проблема общности алтайских языков. Л.: Наука, 1971. С. 90-109.
Владимириов 2005 - Владимирицов Б. Я. Работы по монгольскому языкознанию. М.: Вост. лит., 2005. 952 с.

Исаев 1977 - Исаев Д. Жер-суу аттарынын сыры (= Тайна водяных коней). Фрунзе: Мектеп, 1977. 45 с.

Каратаев 2003 - Каратаев О. Кыргыз этнонимдер сөздүгү (= Киргизский этнографический словарь). Бишкек: Манас, 2003. 265 с.

Кашгари 2012 - Аль-Кашгари Махмуд. Түрк тилдеринин сөздүгү (= Словарь тюркских наречий). Перевод: Т. Токоев, К. Кошмоков. T. II. Бишкек, 2012. 591 с.

Конкашпаев 1956 - Конкашпаев Г. К. Географические названия монгольского происхождения на территории Казахстана // Известия Ан Казахской ССР. Серия филологии и искусствоведения. 1956. Вып. 1. С. 85-98.

Конкобаев 1980 - Конкобаев К. Топонимия Южной Киргизии. Фрунзе: Илим, 1980. $676 \mathrm{c.}$

КМРС 1947 - Краткий монгольско-русский словарь. М., 1947. 427 с.

КРС 1977 - Калмыцко-русский словарь. М.: Русский язык, 1977. 768 с.

КТТС 1969 - Кыргыз тилинин түшүндүрмө сөздүгү (= Толковый словарь кыргызского языка). Т. І. Фрунзе: Мектеп, 1969. 622 с.

Малов 1951 - Малов С. Е. Памятники древнетюркской письменности. М.; Л.: Изд-во AH CCCP, 1951. 452 c.

Монраева 2014 - Монраева Э. М. Способы образования топонимов Синцзян-Уйгурского автономного района (на примере Боро-Тала-Монгольского и Баян-Гол-Монгольского автономных округов СУАР КНР) // Филологические науки. Вопросы теории и практики. Тамбов: Грамота, 2014, № 8 (38). Ч. 2. С. 93-96.

Муканбаев 1972 - Муканбаев Ж. Диалектологический словарь киргизского языка. Фрунзе: Илим, 1972. 712 с.

Мурзаев 1970 - Мурзаев Э. М. Монгольские элементы в топонимике Киргизии // Мат-лы к I съезду Кирг. геогр. общества. Фрунзе: Илим, 1970. С. 7-9.

Мурзаев 1984 - Мурзаев Э. М. Словарь народных географических терминов. М.: Мысль, 1984. 653 c.

Номинханов 1966 - Номинханов Ц. Д. Исследования по тюркским и монгольским языкам. Доклад об опубликованных и выпущенных работах по тюркским и монгольским языкам, представленный в качестве диссертации на соискание ученой степени доктора филологических наук. Алма-Ата, 1966. 26 с. 
Ондар 2007 - Ондар Б. К. Топонимический словарь Тувы. 2-е изд. Кызыл: Тув. кн. издво, 2007. $550 \mathrm{c}$.

Орузбаева 1995 - Орузбаева Б. О. О киргизских и монгольских лексических параллелях в топонимике // Важнейшие проблемы кыргызского языкознания: Сб. ст. Бишкек: Илим, $1995.398 \mathrm{c}$.

Поливанов 1991 - Поливанов Е. И. Труды по восточному и общему языкознанию. М.: Наука; ГРВЛ, 1991. 623 с.

Рамстедт 1957 - Рамстедт Г. Й. Введение в алтайское языкознание: морфология. М.: Изд-во иностр. литературы, 1957. 255 с.

Рассадин 2008 - Рассадин В. И. О монгольских заимствованиях в тюркских языках Южной Сибири // Acta Mongolica. 2008. № 8. С. 2-6.

РКС 1940 - Русско-калмыцкий словарь. М.: Гос. изд-во иностр. и нац. словарей, 1940. $328 \mathrm{c.}$

Санжеев 1947 - Санжеев Г. Д. К тюрко-монгольской лингвистической проблеме // Труды Московского института востоковедов. 1947. № 4. C. 3-24.

Саттаров 1998 - Саттаров Г. Ф. Татарская топонимия. Казань: Казанский университет, 1998. $438 \mathrm{c}$.

Словарь 1988 - Словарь географических названий Киргизской ССР / С. У. Умурзаков, А. А. Кешикбаев, Л. И. Махрина и др.; отв. ред. А. О. Осмонов; Институт геологии АН КиргССР им. М. М. Адышева. Фрунзе: Илим, 1988. $211 \mathrm{c.}$

Строй 1989 - Строй уйгурского языка. АлмаАта: Наука, 1989. 470 с.

Сулайманова 2009 - Сулайманова Л. С. Народные географические термины в топонимии Кыргызстана. Бишкек: Изд-во КРСУ, 2009. $200 \mathrm{c}$.

Сыдыков 1983 - Cыдыков C. Монгольско-тюркские языковые параллели. Фрунзе: Илим, 1983. 165 с.

Убрятова 2011 - Убрятова Е. И. Следы древних тюркского, уйгурского и киргизского языков в современных языках Сибири // Избр. тр. Исследования по тюркским языкам. Новосибирск, 2011. С. 58-67.

Умурзаков 1985 - Умурзаков С. У. Этимологические заметки о некоторых топонимах Киргизии / Ономастика Киргизии. Фрунзе: Илим, 1985. Вып. 1. С. 35-39.

Хойт 2008 - Хойт C. К. Кереиты в этногенезе народов Евразии: историография проблемы. Элиста: Изд-во КалмГУ, 2008. 82 с.
Хонинов 2013 - Хонинов В. Н. Лексико-семантическая характеристика калмыцких топонимов // Нуудэлчдийн ов судлал. Улан-Батор, 2013. С. 251-260.

Эшенкулов 1985 - Эщенкулов T. Из опыта составления топонимических карт Киргизии // Ареальные исследования в языкознании и этнографии: Тез. 5-й конф. на тему «Проблемы атласной картографии». Уфа, 1985. C. $185-186$.

Юдахин 1965 - Юдахин К. К. Киргизско-русский словарь. М.: Советская энциклопедия, 1965. $973 \mathrm{c}$.

Юнусалиев 1959 - Юнусалиев Б. М. Киргизская лексикология. Фрунзе: Киргизское гос. учеб.-педагогич. изд-во, 1959. 248 с.

\section{References}

[Concise Mongolian-Russian Dictionary]. Moscow: Foreign and National Vocabularies State Publ. House, 1947. 427 p. (In Mong. and Russ.)

[Explanatory Dictionary of the Kyrgyz Language]. Vol. I. Frunze: Mektep, 1969. 622 p. (In Kyrg.)

[Kalmyk-Russian Dictionary]. Moscow: Russkiy Yazyk, 1977. 768 p. (In Kalm. and Russ.)

[KirghizASSR: a Dictionary of Place (Geographical) Names]. S. U. Umurzakov, A. A. Keshikbaev, L. I. Makhrina et al. (comps.); A. O. Osmonov (ed.). Adyshev Institute of Geology, Kirghiz SSR Academy of Sciences. Frunze: Ilim, 1988. 211 p. (In Russ.)

[Russian-Kalmyk Dictionary]. Moscow: Foreign and National Vocabularies State Publ. House, 1940. 328 p. (In Russ. and Kalm.)

[Structure of the Uighur Language]. Alma-Ata: Nauka, 1989. 470 p. (In Russ.)

Abdrakhmanov A. A. [Toponymy and Etymology]. Alma-Ata: Nauka, 1975. 207 p. (In Russ.)

Abdullaev S. N. Toponyms of Issyk-Kul Region: variety of spellings revisited. In: [Central Asian Region of the CIS: Russian Language in Educational Environment]. Bishkek: Kyrgyz Russian Slavic University, 2007. Pp. 173-175. (In Russ.)

Ageeva R. [How Names of Rivers and Lakes Appeared: Popular Hyrdonymy]. Moscow: AST-Press, 2012. 288 p. (In Russ.)

Al-Kashgari M. Compendium of the Languages of the Turks. T. Tokoev, K. Koshmokov (transl.). Vol. II. Bishkek, 2012. 591 p. (In Russ.)

Aristov N. A. [The Wusun Kurgyzes, or KaraKyrgyzes]. Bishkek: Ilim, 2001. 578 p. (In Russ.)

Baskakov N. A. [The Language of Issyk-Kul Uighurs]. Alma-Ata: Nauka, 1978. 49 p. (In Russ.) 
Batmanov I. A. [Turkic Languages of Central Asia and South Siberia: Origins and Formation]. Frunze: Ilim, 1966. 360 p. (In Russ.)

Bertagaev T. A. Altaic languages: internal lexical reconstruction and etymology. In: [Altaic Languages: Issues of Commonality]. Leningrad: Nauka, 1971. Pp. 90-109. (In Russ.)

Eshenkulov T. Compiling toponymic maps of Kyrgyzstan: glimpses of experiences. In: [Areal Studies in Linguistics and Ethnography]. Conf. proc. Ufa, 1985. Pp. 185-186. (In Russ.)

Isaev D. [Zher-suu attarynyn syry: The Mystery of Water Horses]. Frunze: Mektep, 1977. 45 p. (In Kyrg.)

Karataev O. [Kyrgyz Ethnographic Dictionary]. Bishkek: Manas, 2003. 265 p. (In Kyrg.)

Khoyt S. K. The Kereits in enthnogenesis of peoples of Eurasia: historiography of the problem. Elista: Kalmyk State University, 2008. 82 p. (In Russ.)

Khoninov V. N. Lexical and semantic characteristics of Kalmyk toponyms. In: [Investigating Nomadic Tribes]. Ulaanbaatar, 2013. Pp. 251260. (In Mong.)

Konkashpaev G. K. Mongolian toponyms of Kazakhstan. Izvestiya AN Kazakhskoy SSR. Ser. 'Philological and Art Studies'. 1956. No. 1. Pp. 85-98. (In Russ.)

Konkobaev K. [Toponymy of Southern Kyrgyzstan]. Frunze: Ilim, 1980. 676 p. (In Russ.)

Malov S. E. [Monuments of Old Turkic Script]. Moscow; Leningrad: USSR Academy of Sciences, 1951. 452 p. (In Russ.)

Monraeva E. M. The ways of toponyms formation of Xinjiang Uighur Autonomous Region (by the example of Bortala Mongol and Bayingholin Mongol Autonomous Prefectures of Xinjiang Uighur Autonomous Region of the People's Republic of China). Philological Sciences. Issues of Theory and Practice. 2014. No. 8 (38). Part 2. Pp. 93-96. (In Russ.)

Mukanbaev Zh. [Kyrgyz Dialect Dictionary]. Frunze: Ilim, 1972. 712 p. (In Russ.)

Murzaev E. M. [Dictionary of Folk Place Names]. Moscow: Mysl, 1984. 653 p. (In Russ.)

Murzaev E. M. Toponymy of Kyrgyzstan: Mongolian elements. In: [First Congress of Kyrgyz Geographical Society]. Proc. Frunze: Ilim, 1970. Pp. 7-9. (In Russ.)
Nominkhanov Ts. D. [Studies on Turkic and Mongolic Languages: a Report on Published Works Submitted as a Doctor of Philology Thesis (Abstract)]. Alma-Ata, 1966. 26 p. (In Russ.)

Ondar B. K. [Toponymic Dictionary of Tuva]. $2^{\text {nd }}$ ed. Kyzyl: Tuvan Book Publ., 2007. 550 p. (In Russ.)

Oruzbaeva B. O. Kyrgyz and Mongolian lexical toponymic parallels revisited. In: [Critical Questions of Kyrgyz Linguistics]. Coll. papers. Bishkek: Ilim, 1995. 398 p. (In Russ.)

Polivanov E. I. [Works on Oriental and General Linguistics]. Moscow: Nauka; GRVL, 1991. 623 p. (In Russ.)

Ramstedt G. J. [Introduction to Altaic Linguistics: Morphology]. Moscow: Inostr. Lit., 1957. 255 p. (In Russ.)

Rassadin V. I. Revisiting Mongolian borrowings in Turkic languages of South Siberia. Acta Mongolica. 2008. No. 8. Pp. 2-6. (In Russ.)

Sanzheev G. D. The Turko-Mongolian linguistic issue revisited. In: [Transactions of Moscow Institute for Oriental Studies]. Moscow, 1947. Vol. 4. Pp. 3-24. (In Russ.)

Sattarov G. F. [Tatar Toponymy]. Kazan: Kazan State University, 1998. 438 p. (In Russ.)

Sulaymanova L. S. [Toponymy of Kyrgyzstan: Folk Place (Geographical) Names]. Bishkek: Kyrgyz Russian Slavic University, 2009. 200 p. (In Russ.)

Sydykov S. [Turko-Mongolian Language Parallels]. Frunze: Ilim, 1983. 165 p. (In Russ.)

Ubryatova E. I. The ancient Turkish, Uighur and Kyrgyz languages: their traces in modern languages of Siberia. In: [Selected Works: Studies on Turkic Languages]. Novosibirsk, 2011. Pp. 58-67. (In Russ.)

Umurzakov S. U. Etymological notes on some toponyms of Kyrgyzstan. In: [Onomastics of Kyrgyzstan]. Frunze: Ilim, 1985. Vol. 1. Pp. 35-39. (In Russ.)

Vladimirtsov B. Ya. [Works on Mongolian Linguistics]. Moscow: Vost. Lit., 2005. 952 p. (In Russ.)

Yudakhin K. K. [Kirghiz-Russian Dictionary]. Moscow: Sovetskaya Entsiklopediya, 1965. 973 p. (In Kyrg. And Russ.)

Yunusaliev B. M. [Kyrgyz Lexicology]. Frunze: Kyrgyz State Educational and Pedagogical Publ., 1959. 248 p. (In Russ.) 